\title{
ENTOMOLOGICAL SURVEILLANCE OF AEDES AEGYPTI AND ARBOVIRUSES OUTBREAK OF DENGUE FEVER IN THE RED SEA GOVERNORATE, EGYPT
}

\author{
By
}

\author{
AZZA A. MOSTAFA, MOHAMMED E. RASHED, NOUR ELDIN S. ALY, \\ AHMED H. HASAN AND MICHEAL W. MIKHAIL*
}

Research Institute of Medical Entomology, Ministry of Health and Population, Dokki, Giza, Egypt ( ${ }^{\star}$ Correspondence: m.w.michy@hotmail.com)

\section{Abstract}

Red sea Governorate coordinates: N $25^{\circ} 32^{\prime} 1^{\prime \prime}$, E $33^{\circ} 26^{\prime} 18^{\prime \prime}$ and one of the borders Governorates. The Red Sea Coast length of $1080 \mathrm{~km}$, from the Gulf of Suez, latitude 29 north, to the border of Sudan on latitude 22 north with about 306,000 living in area of about $203,685 \mathrm{~km}^{2}$ (January 2018), and it is divided into seven cities include Hurghada (capital), Safaga, Al-Kuseer, Ras Ghareb, Marsa Alam, Shalatin, Halaib. Four Cities Hurghada, Safaga, Al-Kuseer, Ras Ghareb were selected for entomological surveys where dengue fever was anticipated to be occurred at November 2017. A total number of 469 houses were participates survived, positive adult houses were $20.47 \%$ (96/469), while positive larvae houses were $10.23 \%$ (48/469). The stogmoyia indices for the parameters of house index (HI), container index $(\mathrm{CI})$ and Breteau index $(\mathrm{BI})$ were $(10.2,7.0 \& 16)$ respectively. The survey yielded a total number of immature stages of Aedes aegypti of $92.22 \%$ (960/1041), or 92.5\% (888/960) for larvae and $7.5 \%$ (72/960) for pupa. The immature stages of other species were recorded 7.78\% (81/1041), Aedes detritus, Culex pipiens, Cx. antennatus and Cx. perexiguus and represented $86.42 \%$ (70/81) for larvae and $13.58 \%$ (11/81) for pupa. Adults Ae. aegypti were 20.36\% (90/442), but adult mosquito of other species were $79.64 \%$ (352/442). Adults Ae. aegypti at Hurghada showed resistant to deltamethrin, cyflothrin and bendiocarb, and suggested resistance to lambda-cyhalothrin, but they were susceptible to malathion. At Safaga City showed resistant for bendiocarb and susceptible to cyflothrin. Larvae of Aedes aegypti at Hurghada City showed resistant to chlorpyrifos, but susceptible to temephos. Also, at Safaga City showed susceptible to temephos insecticide.

Key wards: Red Sea, Aedes aegypti, Dengue virus, Entomological indices, Insecticide bioassay.

\section{Introduction}

Vector-borne infectious diseases are reemerged due to changes in the public health policy, insecticidal and/or the drug resistance, shift in emphasis from the prevention to emergency response, demographic, and the changes in social, climatic and pathogenicity (Gubler, 2009). The climate change is expected to cause extensive shifts in the infectious and vector-borne diseases epidemiology (WHO, 2003). Scenarios on the effects of climate change typically attribute altered the distribution of communicable diseases to the rise in average temperature and altered incidence of infectious diseases to weather extremes (Canyon et al, 2016).

In Egypt, Kirkpatrick (1925) reported Aedes aegypti. Gad (1963) identified Ae. aegypti, Ae. caspius and Ae. detritus. Holstein (1967) stated the complete eradication of the Ae. aegypti from Egypt. But, Heikal et al.
(2011) reported the re-emergency of Ae. aegypti in southern Egyptian border as introduced from the Sudan. Shoukry et al. (2012) detected larvae of Ae. aegypti in water bodies in the Toshka Project. Saleh (2012) reported Ae. aegypti in Aswan Governorate.

Generally, Ae aegypti is the main vector of zoonotic arboviruses; Yellow fever (CDC, 2010), Dengue fever (El-Bahnasawy et al, 2011), Chikungunya viruses (Mostafa et al, 2002) and Zika fever (Morsy, 2018). Also, blood transfusion and needlestick injury must be in mind (Abdel-Motagaly et al, 2017).

Burdino et al. (2011) in North West Italy identified two imported cases of DENV infections from the South Egypt in patients travelling together, confirming the importance of returning travelers as sentinels of the rapidly changing epidemiology in specific geographic areas. They added that there must a careful evaluation and follow-up of 
febrile travellers back from dengue endemic areas. El-Bahnasawy et al. (2011) reported that dengue (DF) and dengue hemorrhagic fevers (DHF) occur in the urban and suburban areas in the Americas, South-East Asia, the Eastern Mediterranean and the Western Pacific, but mainly in rural areas of Africa. They added that Ae. aegypti and endemicity of DF \& DHF in the neighboring regional countries must be in mind of the public health authorities.

Dengue fever cases have been registered earlier in Egypt; the last outbreak was in 2015 in Dairut, but there are no data about outbreaks in cities on coast of the Red Sea (e.g., Hurghada, Sharm El-Sheikh, \& Dahab), which have become resort destinations for Russian citizens (WHO, 2017). Two cases of dengue fever were imported from Hurghada, Egypt, where the DF was not considered endemic, to Moscow. These cases showed how emergence of DF in popular resort regions on the coast of the Red Sea can spread infection to countries where it is not endemic (WHO, 2017).

In October 2017, the health department of the Red Sea Governorate reported cases of dengue fever in El-Qoseir City $145 \mathrm{~km}$ south of Hurghada, with a population of about 50,000 . The preliminary results suggested that 1,200-2,500 persons were infected (ElSheikh, 2017; Saifullin et al, 2018).

This study aimed to investigate Aedes aegypti presence in the Red Sea Governorate, to calculate vector infestation indices, and intervention efficacy, as a marker of transmission and/or sudden outbreak, also to evaluate the efficacy of some insecticides against the yellow fever or tiger mosquito Ae. aegypti under field \& laboratory conditions.

\section{Materials and Methods}

Larvae collection: for $5-20 \%$ of premises according to density HI, CI, BI, Pupal demographic surveillance (WHO, 2017). Data achieved by certain parameters:

$$
\begin{gathered}
\text { House (premise) index }(\mathrm{HI})=\frac{\text { Infested house x } 100}{\text { Inspected house }} \\
\text { Container index }(\mathrm{CI})=\frac{\text { Positive container x 100 }}{\text { Inspected container }} \\
\text { Breteau index }(\mathrm{BI})=\frac{\text { Positive container x 100 }}{\text { Inspected house }}
\end{gathered}
$$

Larval density did not or poorly indicate adult density \& transmission potential (AHI).

$$
\mathrm{AHI}=\frac{\text { House infested by adult } \mathrm{x} 100}{\text { House inspected }}
$$

Adult surveillance: For all premises indoor and outdoor collection using hand aspiration and spay sheet collection. Samples for bioassay from every area were collected, and mosquitoes were identification by international keys (Kent and Chester, 1966; WHO, 2018).

Insecticides susceptibility: The bioassay determined different susceptibility or resistance levels of insecticides on collected mosquitoes' populations. Adult unfed Aedes aegypti, 1-3 days old, reared from collected larvae were used. They were aspirated by a hand aspirator into paper cups to assess the insecticides susceptibility by diagnostic concentration, they were exposed to diagnostic doses for certain times (WHO, 1981) in the plastic chambers and transferred to the clean chambers. Insecticides were $5 \%$ malathion, $0.05 \%$ deltamethrin, $0.05 \%$ lambda-cyhalothrin, $0.15 \%$ cyfluthrin \& $0.1 \%$ bendiocarb.

Larval bioassay: 200 larvae were exposed to diagnostic doses of $0.01 \mathrm{ppm}$ chlorpyriphos \& $0.02 \mathrm{ppm}$ temephos in water for $24 \mathrm{hr}$ at four replicates for each diagnostic concentration and 25 larvae was used as control. Tests were done at $25 \pm 1^{\circ} \mathrm{C} \& 70-$ $80 \%$ relative humidity. Mortality were recorded $24 \mathrm{hr}$ post exposure, by summing dead mosquitoes across all exposure replicates \& expressed as a total number\% of exposed mosquitoes. Control mortality was also calculated. If control mortality was $\geq 20 \%$, test was discarded, but if mortality was $<20 \%$, mortality was corrected by Abbott's formula (1925). If control mortality was $<5 \%$, no co- 
rrection needed, but in control mortality of $\geq 5 \%$, must be corrected.

Statistical analysis: Data collected, tabula- ted and analyzed using the suitable statistical computer software package (SPSS15.0).

\section{Results}

Table 1: Entomological parameters and indices for cities at Red Sea Governorate

\begin{tabular}{|l|c|c|c|c|c|c|c|}
\hline \multicolumn{1}{|c|}{ City } & House count & Positive adult & Positive larvae & HI & CI & BI & AHI \\
\hline Hurghada & 333 & 70 & 30 & 9.0 & 6.0 & 14.1 & 21.6 \\
\hline Safaga & 16 & 3 & 4 & 25 & 15.4 & 37.5 & 18.8 \\
\hline Al-Kuseer & 94 & 21 & 12 & 12.8 & 10.5 & 21.3 & 22.3 \\
\hline Ras Ghareb & 26 & 2 & 2 & 7.7 & 4.0 & 7.7 & 7.7 \\
\hline Total & 469 & 96 & 48 & 10.2 & 7.0 & 16 & 20.9 \\
\hline
\end{tabular}

$\mathrm{HI}=($ house index $) \quad \mathrm{CI}=($ container index $) \quad \mathrm{BI}=($ Breteau index $)$

Of 469 houses, positive adults were $20.47 \%$ (96/469), while positive larvae were $10.23 \%$ (48/469). Stogmoyia indices for HI parameters, CI, \& BI were $10.2,7.0$ \& 16, respectively. Safaga gave high indices $(25$,
15.4 \& 37.5 for HI, CI \& BI, respectively), Ras Ghareb gave lower indices (7.7, 4.0 \& 7.7 respectively) and Hurghada \& Al-Kusser showed $(9.0,6.0 \& 14.1 \& 12.8,10.5 \& 21.3$ respectively).

Table 2: Immature mosquito collected from cities of Red Sea Governorate during autumn 2017

\begin{tabular}{|c|c|c|c|c|c|c|c|c|c|c|c|c|c|c|c|}
\hline \multirow{2}{*}{ City } & \multicolumn{3}{|c|}{ Ae. aegypti } & \multicolumn{3}{|c|}{ Ae. detritus } & \multicolumn{3}{|c|}{ Cx. pipiens } & \multicolumn{3}{|c|}{ Cx. perexiguus } & \multicolumn{3}{|c|}{ Cx. antennatus } \\
\hline & $\mathrm{L}$ & $\mathrm{P}$ & $\mathrm{T}$ & $\mathrm{L}$ & $\mathrm{P}$ & $\mathrm{T}$ & $\mathrm{L}$ & $\mathrm{P}$ & $\mathrm{T}$ & $\mathrm{L}$ & $\mathrm{P}$ & $\mathrm{T}$ & $\mathrm{L}$ & $\mathrm{P}$ & $\mathrm{T}$ \\
\hline Hurghada & 509 & 26 & 535 & 0 & 0 & 0 & 36 & 3 & 39 & 6 & 1 & 7 & 0 & 0 & 0 \\
\hline Safaga & 173 & 23 & 196 & 0 & 0 & 0 & 10 & 1 & 11 & 2 & 0 & 2 & 6 & 4 & 1 \\
\hline Al-Kuseer & 206 & 23 & 229 & 4 & 1 & 5 & 5 & 1 & 6 & 1 & 0 & 1 & 0 & 0 & 0 \\
\hline Total & 888 & 72 & 960 & 4 & 1 & 5 & 51 & 5 & 56 & 9 & 1 & 10 & 6 & 4 & 10 \\
\hline
\end{tabular}

Immature stages were $92.22 \%(960 / 1041)$, $92.5 \%$ (888) larvae \& $7.5 \%$ (72) pupae. Immature stages of others were $7.78 \%(81 /$ 1041), Ae. detritus, Cx. pipiens, Cx. antennatus and $C x$. perexiguus as $86.42 \%$ (70)

Table 3: Adult mosquito collected from cities

larvae and $13.58 \%$ (11) pupae. Immature stages from Hurghada were high $55.73 \%$ $(535 / 960)$ than those from Al-Kuseer $23.85 \%$ (229) and Safaga 20.42\% (173).

\begin{tabular}{|c|c|c|c|c|c|c|c|c|c|c|c|c|c|c|c|}
\hline \multirow{2}{*}{ City } & \multicolumn{3}{|c|}{ Ae. aegypti } & \multicolumn{3}{|c|}{ Ae. detritus } & \multicolumn{3}{|c|}{ Cx. pipiens } & \multicolumn{3}{|c|}{ Cx.perexiguus } & \multicolumn{3}{|c|}{ CX. antennatus } \\
\hline & $\mathrm{M}$ & $\mathrm{F}$ & $\mathrm{T}$ & $\mathrm{M}$ & $\mathrm{F}$ & $\mathrm{T}$ & $\mathrm{M}$ & $\mathrm{F}$ & $\mathrm{T}$ & $\mathrm{M}$ & $\mathrm{F}$ & $\mathrm{T}$ & $\mathrm{M}$ & $\mathrm{F}$ & $\mathrm{T}$ \\
\hline Hurghada & 12 & 54 & 66 & 0 & 0 & 0 & 63 & 131 & 194 & 6 & 18 & 24 & 0 & 0 & 0 \\
\hline Safaga & 2 & 7 & 9 & 0 & 0 & 0 & 3 & 20 & 23 & 0 & 1 & 1 & 6 & 6 & 12 \\
\hline Al-Kuseer & 2 & 13 & 15 & 1 & 4 & 5 & 30 & 63 & 93 & 0 & 0 & 0 & 0 & 0 & 0 \\
\hline Total & 16 & 74 & 90 & 1 & 4 & 5 & 96 & 214 & 310 & 6 & 19 & 25 & 6 & 6 & 12 \\
\hline
\end{tabular}

Ae. aegypti was $20.36 \%$ (90/442). Other Ae. aegypti from Hurghada were $73.33 \%$ adults were $79.64 \%$ (352/442), for Ae.detritus, Cx. perexiguus and $C x$ antennatus. $(66 / 90)$ more than that from Al-Kuseer $16.67 \%(15 / 90)$ and Safaga 10\% (9/90).

Table 4: Adults insecticides bioassay.

\begin{tabular}{|c|c|c|c|c|c|c|}
\hline \multirow{4}{*}{ Area } & $\begin{array}{c}\text { Insecticide } \\
\text { group }\end{array}$ & $\begin{array}{c}\text { Insecticide } \\
\text { used }\end{array}$ & $\begin{array}{c}\text { Diagnostic } \\
\text { dose } \%\end{array}$ & $\begin{array}{c}\text { No. } \\
\text { adults }\end{array}$ & $\begin{array}{c}\text { Corrected } \\
\text { mortality } \%\end{array}$ & $\begin{array}{c}\text { Susceptibility } \\
\& \text { resistant }\end{array}$ \\
\hline \multirow{4}{*}{ Hurghada } & Deltamethrin & 0.05 & 50 & 88.75 & Resistant \\
\cline { 3 - 7 } & Pyrethroid & $\begin{array}{c}\text { Lambada } \\
\text { cyhalothrin }\end{array}$ & 0.05 & 50 & 91.25 & $\begin{array}{c}\text { Suggested } \\
\text { resistant }\end{array}$ \\
\cline { 2 - 7 } & Carbamate & Cyflothrin & 0.15 & 50 & 83.75 & Resistant \\
\cline { 2 - 7 } & Organophosphorus & Malathion & 5.0 & 50 & 100 & Susceptible \\
\hline \multirow{3}{*}{ Safaga } & Pyrethroid & Cyflothrin & 0.15 & 50 & 100 & Susceptible \\
\cline { 2 - 7 } & Carbamate & Bendiocarb & 0.1 & 50 & 19.4 & Highly resistant \\
\hline
\end{tabular}

At Hurghada, adults showed resistant to deltamethrin, cyflothrin and bendiocarb, and showed suggested resistance to lambda cyhalothrin, but susceptible to malathion. At Sa- 
faga they showed resistant to bendiocarb and susceptible to cyflothrin insecticides.

Table 5: Larvae insecticides bioassay

\begin{tabular}{|c|c|c|c|c|c|c|}
\hline \multirow{2}{*}{ Area } & $\begin{array}{c}\text { Insecticide } \\
\text { group }\end{array}$ & $\begin{array}{c}\text { Insecticide } \\
\text { used }\end{array}$ & $\begin{array}{c}\text { Diagnostic } \\
\text { dose PPM }\end{array}$ & Larvae & $\begin{array}{c}\text { Corrected } \\
\text { mortality \% }\end{array}$ & $\begin{array}{c}\text { Susceptibly } \\
\text { \& Resistant }\end{array}$ \\
\hline \multirow{3}{*}{ Hurghada } & \multirow{2}{*}{$\begin{array}{c}\text { Organopho- } \\
\text { sphorus }\end{array}$} & Chlorpyriphos & 0.01 & 100 & 8 & Highly resistant \\
\cline { 3 - 7 } & Safaga & Temephos & 0.02 & 100 & 100 & Susceptible \\
\cline { 3 - 7 } & & Temephos & 0.02 & 100 & 100 & Susceptible \\
\hline
\end{tabular}

Larvae at Hurghada resisted chlorpyrifos, but were susceptible to temephos. At Safaga larvae showed susceptible to temephos.

\section{Discussion}

Generally, application of fogging usually is not effective in reducing the density of adult Aedes mosquito due to the indoor nature of such vector, so intimate application and community mobilization is the very important to encourage the people to open the windows during fogging. Other application of adult mosquito pesticide (e.g.; residual spray) is also not effective and not recommended hence the behavioral nature of resting places of such vector, but aerosol domestic spraying may be effective. The AHI/ $\mathrm{HI}$ indices indicated that more than $50 \%$ of infested houses come from neighbors' breeding places and the mosquitoes visited these houses for feeding and resting places hence, use of doors and windows specific mosquito netting was very indicated.

As to mosquitoes, Gad and Salit (1973) in Ras-Ghareb, Hurghada, Safaga and Koseir reported Anopheles multicolor, Ae. caspius and $C x$. pipiens. Mostafa et al. (2002) reported that Culex species were the commonest; $C x$. pipiens, $C x$. antennatus and $C x$. univittatus. Cx. thelerei was found only in ElKharga oasis. Aedes detritus was found in Assiut, El-Fayium, Giza, El-Wady El-Gadeed and South Sinai, and Ae. caspius was coomon in Assiut and Aswan Governorates. Mikhail et al. (2009) in Egypt reported that mosquitoes were six species of Culex, 13 Anopheles species, only Aedes caspius, Ae. detritus, and Culiseta longiareolata.

WHO (2015) reported that a DF outbreak with at least 253 cases in Assiut Governorate. Abozeid et al. (2018) showed that Ae. aegypti caused dengue fever outbreak of more than 680 cases in the Red Sea Governorate. Abdelkader (2018) reported the PCR positivity of 101 people suffered from the dengue fever in both the Red Sea and Qena Governorates.

The abuse of insecticides for mosquito larvae might be the reason for resistance. WHO (1992) reported that in the Eastern Mediterranean Countries $C x$. pipiens larvae were resistant to the organophosphorus insecticides. Thavaselvan et al. (1993) in Indian reported that An. stephensi, Cx. quinquefaciatus and Ae. aegypti larvae were resistant to malathion and fenitrothion. Mazzarri and Georghiou (1995) in Venezuela found Ae. aegypti resisted temephos, malathion and pirimiphos methyl, and propoxur, but with moderate resisted to permethrin and lambda-cyhalothrin. Zayed et al. (1997) in Giza, Beheira, Demiatta \& Assiut Governorates reported that $C x$. pipiens larvae were resistant to chloropyrifos, fenitrothion, fenthion, malathion and temephos. Mostafa and Allam (2001) in ElFayiom Governorate found that $C x$. pipiens larvae resisted temphos, fenitrothon, bromophos and fenthion, but were susceptible to malathion, permethrin and diazinon. Zayed et al. (2006) in Qalyobia Governorate found that $C x$. pipiens larvae were susceptible to malathion but resisted lambada-cyhalothrin, permethrin, cyfluthrin, propxur, fenitrothion and bendiocarb. Mikhail et al. (2007) in Qatar reported that the chloropyrifos and cyfluthrin were highly effective larvicides for the $C x$. pipiens complex, cyphenothrin was moderate resistant, but propetamphos, and etofanprox was the least ones.

Al-Sarar (2010) in Riyadh found that two $C x$. pipiens populations from Wadi Namera were highly resistant to deltamethrin, the third one from Al-Wadi District had low resist- 
ance to lambada-cyhalothrin and moderate resistance to betacyfluthrin, and bifenthrin.

Abd-El-Samie and Abd-El-Baset (2012) in Sharkia and Assiut Governorates studied the efficacy of organophosphorus, carbamate, and synthetic pyrethroid as well as the insect growth regulator against $C x$. pipiens field and laboratory populations. They found that the laboratory mosquitoes were highly susceptibility to insecticides than the field ones. Alsheikh et al. (2016) in Saudi Arabia found that Ae. aegypti adult and larvae were susceptible to cyfluthrin, with variable resistances to lambda-cyhalothrin, deltamethrin, permethrin, fenitrothion, bendiocarb and DDT. The larvae was resistant to temephos, but high susceptibility to the methoprene than diflubenzuron (IGRs).

\section{Conclusion}

Generally speaking, the dengue virus in fection in humans is often unapparent but can lead to a wide range of clinical manifestations, from mild fever to potentially fatal shock syndrome. Meanwhile, its vector is difficult to controlling as having wide range of breading places.

The outcome results showed that the Red Sea Governorate has high Ae. aegypti density and consequently dengue fever suspected.

Meanwhile, the extensive abuses of the insecticides pave the way to the mosquitoes' as well as other insects for insecticidal resistance. Consequently, the Aedes aegypti regular periodical control of both adults and larvae, as well as the development of new friendly control measure are recommended.

\section{References}

Abbott, WS, 1925: A method of computing of the effectiveness of an insecticide. J. Entomol. 18, 2:265-67.

Abdel-Motagaly, AME, Ibrahim, AMA, Morsy, TA, 2017: An intervention program on blood protozoa acquired by needle stick injury and infection control. J. Egypt. Soc. Parasitol. 47, 2: 309-22.

Abd-El-Samie, E, Abd-El-Baset, T, 2012: Efficacy of some insecticides on field populations of Culex pipiens (Linnaeus) from Egypt. J. Basic
Appl. Zool. 65:62-73.

Abdelkader, NA, 2018: Dengue fever. Egypt. J. Inter. Med. 30, 1:47-9.

Abozeid, S, Elsayed, AK, Sehaffner, F, Samy, AM, 2018: Re-emergence of Aedes aegypti in Egypt. Lancet Infect. Dis.18, 2: 142-3.

Al-Sarar, AS, 2010: Insecticide resistance of Culex pipiens (L.) populations (Diptera: Culicidae) from Riyadh city, Saudi Arabia: Status and overcome. Saudi J. Biol. Sci. 17:95-100.

Alsheikh, AA, Mohammed, WS, Noureldin, E M, Daffalla, OM, Shrwani, YA, et al, 2016: Studies on Aedes aegypti resistance to some insecticides in the Jazan District, Saudi Arabia. J. Egypt. Soc. Parasitol. 46, 1:209-16.

Burdino, E, Ghisetti, V, 2011: Diagnosis of dengue fever in North West Italy in travelers from endemic area. J. Clin. Virol. 15, 4:259-63.

Canyon, DV, Speare, R, Burkle, FM, 2016: Forecasted impact of climate change on infectious disease and health security in Hawaii by 2050. Disaster Med. Publ. Hlth. Prep. 10, 6:797804

CDC, 2010: Fact Sheet/Yellow Fever. http:// www.cdc.gov/ncidod/dvbid/yellowfever/yf_facts heet.html.

El-Sheikh, S, 2017: Only 5\% of Al-Qoseir Citizens infected with dengue fever: Health Minister. https://dailynewsegypt.com/10/12/5 alqoseircitizens-infected-denguefever-healthministry.

El-Bahnasawy, MM, Khalil, HH, Morsy, AT, Morsy TA, 2011: Threat of dengue fever and dengue hemorrhagic fever to Egypt from travelers. J. Egypt. Soc. Parasitol. 41, 2:289-306.

Gad, AM, 1963: Insects of Medical Importance. Research Institute of Medical Entomology, The Egyptian Ministry of Health, Dokki, Giza.

Gad, AM, Salit, A, 1973: The mosquitoes of the Red Sea Area, Egypt. J. Med. Entomol. 6:58182.

Gubler, DJ, 2009: Vector-borne diseases. Rev. Sci. Tech. 28, 2:583-8.

Heikal, OM, El-Bahnasawy, MM, Morsy, AT A, Khalil, HHM, 2011: Aedes aegypti re-emerging in Egypt: A review and what should be done? J. Egypt. Soc. Parasitol. 41, 3:785-814.

Holstein, M. 1967: Dynamics of Aedes aegypti: Distribution, density and seasonal prevalence in the Mediterranean Area. Bull. Org. Mon. Santre, WHO 36:541-3.

Kent SL, Chester JS, 1966: Pictorial keys to arthropods, reptiles, birds and mammals of public health significance: Mosquitoes: characteris- 
tics of anopheline and culicine. Department of Health, Education, and Welfare, Public Health Service, Atlanta, Georgia U.S..

Mazzarri, MB, Georghiou, GP, 1995: Characterization of resistance to organophosphate, carbamate, and pyrethroid insecticides in field populations of Aedes aegypti from Venezuela. J. Am. Mosq. Cont. Assoc. 11, 3: 315-22.

Mikhail, MW, Al-Bursheed KM, Allam, KM, 2007: Susceptibility of Culex pipiens complex to some insecticides in Qatar. J. Egypt. Soc. Parasitol. 37, 3:893-902.

Mikhail, MW, Al-Bursheed, KM, Abd-El-Halim, AS, Morsy, TA, 2009: Studied on mosquito borne diseases in Egypt and Qatar. J. Egypt. Soc. Parasitol. 39, 3:745-56.

Morsy, TA, 2018: Aedes aegypti and dengue virus infections. J. Egypt. Soc. Parasitol. 48, 1: 183-96.

Mostafa, AA, Allam, KA, 2001: Studies on the present status of insecticides resistance on mosquitoes using the diagnostic dosages in El-Fayiom Governorate: A spot area of malaria in Egypt. J. Egypt. Soc. Parasitol. 31, 1:23-40.

Mostafa, AA, Allam, K, Osman, M, 2002: Mosquito species and their densities in some Egyptian Governorates. J. Egypt. Soc. Parasitol. 32, 1:9-20.

Saifullin, MA, Laritchev, VP, Grigorieva, Y E, Zvereva, NN, Domkina, AM,2018: Two cases of dengue fever imported from Egypt to Russia, 2017 Emer. Infect. Dis. Apr 17; 24(4). doi: 10.3201/eid2404.172131.

Saleh, NM, 2012: Aedes mosquito in Aswan Governorate, Egypt. J. Egypt. Soc. Parasitol. 42, 1:233-8.

Seufi, AM, Galal, FH, 2010: Role of Culex and Anopheles mosquito species as potential vectors of rift valley fever virus in Sudan outbreak, 2007. BMC Infect. Dis. 10:65-74.
Shoukry, NM, Elwan, MA, Morsy, TA, 2012: Aedes aegypti (Linnaeus) re-emerging in southern Egypt. J. Egypt. Soc. Parasitol. 42, 1:41-50.

Thavaselvan, D, Kumar, A, Samoan, P, 1993: Insecticide susceptibility status of Anopheles stephensi, Culex quinquefaciatus and Aedes aegypti in Punjabi. Indian J. Malariol. 30, 3:75-96.

WHO, 1981: Instruction for determining the susceptibility or resistance of mosquito larvae to insecticides. Geneva, Switzerland: WHO. WHO/ VBC/81.807, Geneva, Switzerland.

WHO, 1992: Vector Resistance to Pesticides: The WHO Export Committee on VBC. The $15^{\text {th }}$ Tech. Rep. No.818, Geneva, Switzerland.

WHO, 2003: Guidelines for Dengue Surveillance and Control. $2^{\text {nd }}$ Edition, WHO Library Cataloguing in Publication Data, Geneva, Switzerland.

WHO, 2015: Dengue Fever, Egypt http:// www.who.int/csr/don/12-november.dengue/en

WHO, 2017: Dengue fever, Egypt. http:// www.who.int/csr/don/12-november-2017dengue

\section{len/}

WHO, 2018: Weekly bulletins on outbreaks and other emergencies. http://www.afro.who.int/ health-topics/disease-outbreaks/outbreaks-and-other-emergencies-updates?page $=0$

Zayed, AB, Mostafa, AA, Osman, MZ, Kotb, NA, 1997: Susceptibility of Culex pipiens complex mosquito to some insecticides in Egypt. AlAzhar Bull. Sci. 8:293-8.

Zayed, AB, Szumlas, DE, Hanafi, HA, Fryauff, DJ, Mostafa, AA, et al, 2006: Use of bioassay and microplate assay to detect and measure insecticide resistance in field populations of Culex pipiens from filariasis endemic areas of Egypt. J. Amer. Mos. Cont. Assoc. 22, 3:473-82. 